\title{
CORRESPONDENCE
}

To the Editor.

Dear Sir,

\section{Covenants and Privity of Contract}

In his interesting article on the above, Andrew Tettenborn criticises the Court of Appeal in Swiss Bank v. Lloyds Bank [1980] 3 W.L.R. 457 for accepting counsel's concession that the De Mattos v. Gibson principle was of no value to Swiss Bank unless its right (to have the proceeds of sale of and the income from the F.I.B.I. securities applied exclusively to pay off its own debt) was specifically enforceable so as to make Swiss Bank an equitable chargee and thus the owner of a proprietary interest in the F.I.B.I. securities. It is said that this must be wrong, since it assumes that no interest not being a proprietary interest can prevail against a purchaser of personality.

In fact, the "concession" was actually an acceptance of a submission made by counsel for Lloyds Bank which, it is respectfully suggested, was plainly right. He analysed Swiss Bank's argument based on De Mattos v. Gibson as follows:

(i) The premise must be that Swiss Bank had no equitable charge or proprietary interest in the F.I.B.I. securities (or the argument was mere surplusage);

(ii) Lloyds Bank took its charge with notice of Swiss Bank's rights, and could be restrained from resorting to the F.I.B.I. securities inconsistently with those rights. Lloyds Bank could not, however, be restrained from selling the F.I.B.I. securities, since this was permitted by Swiss Bank's contract. Unless the remedy of specific performance was available, Lloyds Bank could not be compelled actually to pay the proceeds to Swiss Bank; it could presumably keep them.

(iii) Moreover, I.F.T. was in insolvent liquidation. An injunction to restrain Lloyds Bank from enforcing its security would not prevent the liquidator of I.F.T. from realising the F.I.B.I. securities and distributing the proceeds pari passu among the unsecured creditors. Lloyds Bank was owed some thirty times more than Swiss Bank, and other creditors were negligible.

(iv) Thus the argument merely led to the possible invalidity of Lloyds Bank's charge, but it could not conceivably give Swiss Bank priority.

(v) If the argument went further, and involved restraining the liquidator of I.F.T. from paying creditors (including Lloyds Bank) until Swiss Bank was paid in full, then either:

(a) it created a charge (which was contrary to the premise); or

(b) it led to a distribution of the assets of an insolvent company which was contrary to the mandatory requirements of section 302 of the Companies Act 1948.

The short point is that no interest except a proprietary interest (either absolute or by way of security) can prevail against unsecured 
creditors in an insolvency. It follows that it cannot give priority over a subsequent mortgagee, or an impossible circle of priorities results. These are insuperable limitations to the principle of De Mattos v. Gibson, and should be recognised as such.

\section{P. J. MILLETT (Q.C.)}

9 Old Square,

Lincoln's Inn, W.C.2.

\section{Mr. Tettenborn comments:}

The point that there could be no holding Lloyds Bank to the covenant entered into by I.F.T. in respect of the F.I.B.I. shares unless that covenant created an equitable proprietary interest in those shares, I accept was agreed by counsel in the course of argument and not simply conceded. This was not entirely clear from the terms of the judgment and I am most grateful to Mr. Millett for drawing it to my attention.

However, the assertion on which Mr. Millett's main argument rests, that no claim except a proprietary claim can ever succeed against unsecured creditors in an insolvency, I submit is misconceived. Assume, for example, a company covenants with $X$ not to build on certain land adjoining $X$ 's land and later becomes insolvent. It must surely be the case that, despite the insolvency, the covenant remains enforceable if necessary by injunction. Yet, I would suggest, according to Mr. Millett's argument this would not be the case ; instead the company (or rather, its liquidator) must be allowed to break the covenant, build on the land and leave $\mathrm{X}$ to his unsecured right of action for damages for breach of contract. For otherwise a non-proprietary interest would have been allowed to prevail against the general creditors in the insolvency-and, moreover, to prejudice them too, if it would have been profitable for the company to break the covenant even taking into account any damages they might have to pay for doing so.

In other words, the very point I am trying to make is that the rights that prevail against general creditors in insolvency are not, as is often thought, those classified as "proprietary" as such, but instead a slightly different class-those that are enforceable specifically (whether by specific performance or injunction) rather than pecuniarily (by damages). In practice it will often not matter how the distinction is drawn, but this is only because those rights that are enforceable specifically tend to be those that are also regarded as proprietary (the idea that injunctions only issue to protect "property" is a misguided but understandable reflection of this fact). It is in the exceptional cases such as De Mattos v. Gibson that I have suggested that the precise class of rights that will prevail in an insolvency does matter. 